\title{
RESEARCH
}

Open Access

\section{Purification and enzymatic characterization of a novel metalloprotease from Lachesis muta rhombeata snake venom}

Francielle Almeida Cordeiro', Bárbara Marques Coutinho ${ }^{1}$, Gisele Adriano Wiezel', Karla de Castro Figueiredo Bordon ${ }^{1}$, Cristiane Bregge-Silva², Nathalia Gonsales Rosa-Garzon ${ }^{3}$, Hamilton Cabral ${ }^{3}$, Beatrix Ueberheide ${ }^{4}$ and Eliane Candiani Arantes $^{1 *}$ (i)

\begin{abstract}
Background: Lachesis muta rhombeata (Lmr) is the largest venomous snake in Latin America and its venom contains mainly enzymatic components, such as serine and metalloproteases, L-amino acid oxidase and phospholipases $\mathrm{A}_{2}$. Metalloproteases comprise a large group of zinc-dependent proteases that cleave basement membrane components such as fibronectin, laminin and collagen type IV. These enzymes are responsible for local and systemic changes, including haemorrhage, myonecrosis and inflammation. This study aimed the isolation and enzymatic characterization of the first metalloprotease ( $L m r-M P)$ from $L m r$ venom ( $L m r V)$.

Methods and results: Lmr-MP was purified through two chromatographic steps and submitted to enzymatic characterization. It showed proteolytic activity on azocasein with maximum activity at pH 7.0-9.0. It was inhibited by EDTA (a metal chelator that removes zinc, which is essential for enzymatic activity) and no effect was observed with PMSF, iodoacetic acid or pepstatin (inhibitors of serine, cysteine and aspartyl proteases, respectively). $\mathrm{Ca}^{2+}, \mathrm{Mg}^{2+}$ and $\mathrm{Ba}^{2+}$ ions increased its activity, while $\mathrm{Al}^{3+}, \mathrm{Cu}^{2+}, \mathrm{Ni}^{2+}$ and $\mathrm{Zn}^{2+}$ inhibited it. Additionally, $\mathrm{ZnCl}_{2}$ showed a dose dependent inhibition of the enzyme. Lmr-MP activity was also evaluated upon chromogenic substrates for plasma kallikrein (S-2302), plasmin and streptokinase-activated plasminogen (S-2251) and Factor Xa (S-2222) showing the highest activity on S-2302. The activity in different solutions $(5 \mathrm{mM}$ or $50 \mathrm{mM}$ ammonium bicarbonate, $\mathrm{pH}$ 7.8; $0.1 \%$ trifluoroacetic acid $+50 \%$ acetonitrile; phosphate buffer saline, $\mathrm{pH} 7.4 ; 50 \mathrm{mM}$ sodium acetate, $\mathrm{pH} 4.0$ or ammonium acetate $\mathrm{pH}$ 4.5) was also evaluated and the results showed that its activity was abolished at acidic pHs. Its molecular mass $(22,858 \mathrm{Da}$ ) was determined by MALDI-TOF and about $90 \%$ of its primary structure was verified by high-resolution mass spectrometry using HCD and ETD fragmentations and database search against the sequence of closely related species. It is a novel enzyme which shared high identity with other snake venom metalloproteases (svMPs) belonging to the P-I group.
\end{abstract}

Conclusion: The purification procedure achieved a novel pure highly active metalloprotease from LmrV. This new molecule can help to understand the metalloproteases mechanisms of action, the Lachesis envenoming, as well as to open new perspectives for its use as therapeutic tools.

Keywords: Lachesis muta rhombeata, Metalloprotease, Proteases, Snake venom

\footnotetext{
* Correspondence: ecabraga@fcfrp.usp.br

${ }^{1}$ Department of Physics and Chemistry, School of Pharmaceutical Sciences of Ribeirão Preto, University of São Paulo (USP), Av. do Café s $/ n^{\circ}$, Monte Alegre, Ribeirão Preto, SP 14040-903, Brazil

Full list of author information is available at the end of the article
}

(c) The Author(s). 2018 Open Access This article is distributed under the terms of the Creative Commons Attribution 4.0 International License (http://creativecommons.org/licenses/by/4.0/), which permits unrestricted use, distribution, and reproduction in any medium, provided you give appropriate credit to the original author(s) and the source, provide a link to the Creative Commons license, and indicate if changes were made. The Creative Commons Public Domain Dedication waiver (http://creativecommons.org/publicdomain/zero/1.0/) applies to the data made available in this article, unless otherwise stated. 


\section{Background}

Brazil is one of the countries with the highest number of accidents caused by terrestrial animals, such as scorpions, spiders, snakes, bees and caterpillars wherein more than $54 \%$ of them are due to snakes bites [1]. In 2016, the number of accidents caused by snakes in Brazil was 26,295 (under review) and the most dangerous snake genera are Bothrops, Crotalus and Lachesis, the latter representing around 3\% of accidents [2]. However, in Northern Brazil the Lachesis accidents reach up to 9\% [1]. Although the number of accidents is lower than those caused by Bothrops and Crotalus, the Lachesis bites cause a severe envenoming with hypotension, bleeding, pain and a vagal syndrome with diarrhoea, nausea and vertigo [3-5].

Lachesis genus, known as "bushmasters", are the largest snakes in Latin America and the only pit vipers in Brazil that lay eggs [6, 7]. They are currently classified in Lachesis stenophrys, Lachesis melanocephala (Central America), Lachesis acrochorda and Lachesis muta (South America). L. muta is found in Brazil and subdivided into two subspecies: L. muta muta (Amazon tropical forest) and L. muta rhombeata (Atlantic forest) [5, 6, 8].

Among the components identified in Lachesis muta rhombeata venom (LmrV), are a hyaluronidase [9], phospholipases $\mathrm{A}_{2}\left(\mathrm{PLA}_{2}\right)[10,11]$, phospholipase B (PLB) [9], L-aminoacid oxidase (LAAO) [12], serine protease [9] and bradykinin-potentiating peptides (BPPs) [13]. Although two snake venom metalloproteases (SVMPs) have been identified in L. muta muta venom (LmmV), this is the first study with metalloprotease from LmrV.

Metalloproteases are one of the most abundant toxins in Viperid venoms. They are zinc-dependent proteases that cleaves the extracellular matrix (collagen, laminin and fibronectin) and can cause blood coagulation disorders. As consequence, they can lead to haemorrhage, fibrinogenolytic activity, activation of factor X and platelet aggregation inhibition $[14,15]$.

SVMPs were initially classified into P-I to P-IV classes, however, Fox and Serrano [16] proposed that P-IV class should be inserted into P-III. Therefore, SVMPs were currently classified into P-I, P-IIa and PIIb, and P-IIIa to P-IIId. P-I MPs have 20-30 kDa and contain only the metalloprotease catalytic domain; P-II MPs present 30-60 kDa with protease and disintegrin domains and P-III MPs are within the range of $60-100 \mathrm{kDa}$ with protease, disintegrin and cysteine-rich domain sites $[14,16]$.

SVMPs have been studied for several therapeutic purposes. Since they interact with cell membrane components, these enzymes have been shown to inhibit angiogenesis, cell migration and adhesion, which are important mechanisms in cancer proliferation and makes these enzymes important tools in metastatic tumours treatment [17-20]. Metalloproteases also can act as therapeutic tools in arthritis disorders $[21,22]$ and in haemostatic diseases [23].
In this study, we isolated the first metalloprotease from Lachesis muta rhombeata venom (Lmr-MP) and its enzyme activity was characterized against azocasein, under different ion concentrations and with the substrates plasma kallikrein (S-2302), plasmin, streptokinase-activated plasminogen (S-2251) and Factor Xa (S-2222). Furthermore, we determined the optimal $\mathrm{pH}$ and the mass spectrometry analysis revealed that the glycosylation site observed in other snake metalloproteases is absent in Lmr-MP. The discovery of this new molecule can help to elucidate some mechanisms of action in Lachesis envenoming, as well as to contribute to treatment improvement and development of a therapeutic tool for haemostatic diseases.

\section{Methods}

\section{Lachesis muta rhombeata venom}

The LmrV was acquired from the Serpentarium Bosque da

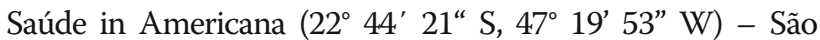
Paulo - Brazil (IBAMA authorization: 647.998). The venom was collected, desiccated and stored at $-20{ }^{\circ} \mathrm{C}$ until use.

\section{Isolation}

The crude LmrV (around $23 \mathrm{mg}$ ) was dispersed in $500 \mu \mathrm{L}$ of $0.05 \mathrm{M}$ sodium acetate buffer with $0.15 \mathrm{M}$ $\mathrm{NaCl}, \mathrm{pH}$ 6.0, centrifuged at $13,400 x g$ at $4{ }^{\circ} \mathrm{C}$ for $10 \mathrm{~min}$ and the supernatant was filtered on a HiPrep Sephacryl ${ }^{\oplus}$ S-100 HR column $(1.6 \times 60 \mathrm{~cm}$, GE Healthcare, Sweden) under a flow rate of $0.5 \mathrm{~mL} / \mathrm{min}$.

The LmS-6 fraction obtained from the previous step was dispersed in buffer A (0.05 M MES - 2-( $N$-morpholino)ethanesulfonic acid, $\mathrm{pH}$ 6.0) and submitted to an ion exchange chromatrography on a HiTrap ${ }^{\mathrm{TM}}$ IEX SP XL column $(0.7 \times 2.5 \mathrm{~cm}, 1 \mathrm{~mL}$, GE Healthcare $)$. The elution followed a concentration gradient from 0 to $1.0 \mathrm{M} \mathrm{NaCl}$ in the same buffer under a flow rate of $0.5 \mathrm{~mL} / \mathrm{min}$. The isolation was performed in FPLC Äkta Purifier UPC 900 system with monitoring of $280 \mathrm{~nm}$.

\section{SDS-page}

Sodium dodecyl sulfate polyacrylamide gel electrophoresis (SDS-PAGE) was performed according to Laemmli [24]. A resolution gel containing $13.5 \%(\mathrm{~m} / \mathrm{v})$ bisacrylamide/acrylamide, $1 \mathrm{M}$ Tris- $\mathrm{HCl}$ buffer and $0.1 \%$ sodium dodecyl sulfate (SDS) was prepared. The concentration gel was prepared with $5 \%$ acrylamide in $0.5 \mathrm{M}$ Tris- $\mathrm{HCl}$ buffer and $0.1 \%$ SDS. The SDS-PAGE was performed under reducing conditions. The SDS-PAGE gel was performed to monitor the isolation process and sample migration was compared to molecular mass standards (Sigma M3913 and M0671).

\section{Mass spectrometry analysis by MALDI-TOF}

The molecular mass of Lmr-MP was determined by MALDI-TOF (Matrix Assisted Laser Desorption/Ionization - 
Time of Flight) in an Ultraflex II (Bruker Daltonics - DE) mass spectrometer, with a laser source of Nd SmartBeamYAG laser type (MLN 202, LTB). The solution $(1 \mu \mathrm{L})$ containing Lmr-MP $(5 \mu \mathrm{g})$ was spotted with sinapinic acid (SA) matrix $(10 \mathrm{mg} / \mathrm{mL}$ in a solution containing $0.2 \%$ trifluoracetic acid and $80 \%$ acetonitrile), in the proportion of $1: 1(V / \mathrm{V})$. Ions were detected using a linear positive mode and calibrated with protein standards from Bruker Daltonics.

\section{Amino acid sequence determination}

The metalloprotease amino acid sequence characterization was performed with lane 5 from SDS-PAGE (Fig. 1b insert). The gel band was destained with a solution containing $100 \mathrm{mM}$ ammonium bicarbonate (AMBIC: MetOH (50:50) and dehydrated with $100 \%$ acetonitrile (ACN). After this, sample was reduced with $100 \mu \mathrm{L}$ of 1,4-dithiothreitol (3 mg/ $1000 \mu \mathrm{L} 100 \mathrm{mM}$ AMBIC) for $1 \mathrm{~h}$ at $57{ }^{\circ} \mathrm{C}$ and alkylated with $100 \mu \mathrm{L}$ of iodoacetamide $(9 \mathrm{mg} / 1000 \mu \mathrm{L} 100 \mathrm{mM}$ AMBIC) for $45 \mathrm{~min}$, at room temperature and within a dark compartment. For digestion, $222 \mathrm{ng}$ of modified trypsin (Promega $^{\mathrm{Tm}}$, USA) in $160 \mu \mathrm{L}$ of $100 \mathrm{mM}$ AMBIC was added and sample was incubated at $25^{\circ} \mathrm{C}$, overnight.

The digested peptides were submitted to an EASY-Spray PepSwift Monolithic Capillary column (Thermo Scientific ${ }^{\mathrm{m}}$ ) with an Easy-nLC 1000 (Thermo Scientific $^{\mathrm{Tw}}$ ) coupled to an Orbitrap Elite ${ }^{\mathrm{Tm}}$ Mass Spectrometer (Thermo Scientific ${ }^{\mathrm{Tm}}$, USA). The tryptic peptides were eluted in 65 min using a gradient of ACN from 2 to $90 \%$ in $0.5 \%$ acetic acid and two independent runs were made. In the first run, the MS spectra were obtained with resolution of 60,000 (at $\mathrm{m} / \mathrm{z} 400$ ) and automatic gain control (AGC) target of 1e6. Subsequently, twenty data-dependent $\mathrm{HCD}$ MS/MS were acquired with a resolution of 15,000 (at m/z 400), AGC target of $5 \mathrm{e} 4$, normalized collision energy of 35 , and isolation window of $\pm 2 \mathrm{Da}$. In the second run, the MS resolution were obtained with resolution of 120,000 and automatic gain control (AGC) target of 5e4. Twenty data-dependent ETD MS/MS were acquired with a resolution of 15,000 (at $\mathrm{m} / \mathrm{z}$ 400), AGC target of 5e4, activation time of $60 \mathrm{~ms}$, and isolation window of $\pm 3 \mathrm{Da}$.

Data from both runs were searched by the software Byonic $^{\mathrm{ma}}[25]$ against a database downloaded from UniProt using the keywords "metalloproteinase" and "Lachesis" (accession in 07/01/15). Mass tolerance was set as $10.0 \mathrm{ppm}$ for precursor ions and $20.0 \mathrm{ppm}$ for their fragments. Cysteine carbamidomethylation was set as fixed modifications whereas variable modifications included oxidation of methione, $\mathrm{N}$-terminal pyro-glutamate, amidated C-terminal, and HexNAc (N-acetylglucosamine) for $\mathrm{N}$-glycosylation. A wildcard feature of $\pm 150 \mathrm{Da}$ was enabled to search for amino acid substitutions in comparison to the database. The identified peptides were manually checked, specially those different from the database entries.

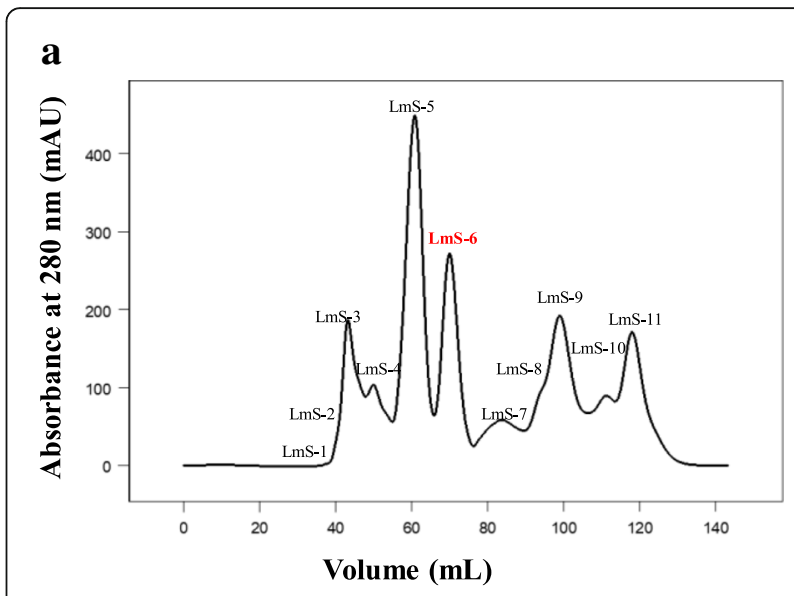

b

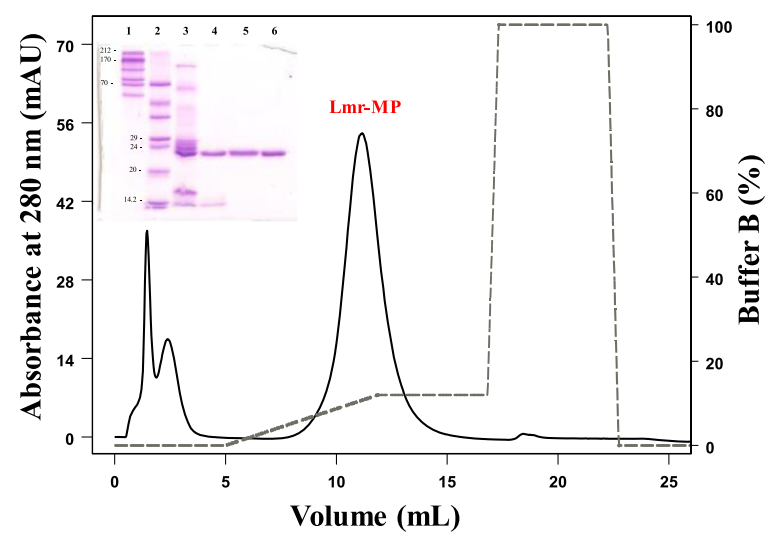

Fig. 1 Chromatographic profiles of metalloprotease from L. m. rhombeata venom. a Fractionation of Lachesis muta rhombeata venom by molecular exclusion chromatography on a HiPrep Sephacry ${ }^{\circledR}$ S-100 HR column $(1.6 \times 60 \mathrm{~cm})$ using $0.05 \mathrm{M}$ sodium acetate buffer with $0.15 \mathrm{M} \mathrm{NaCl}$, $\mathrm{pH}$ 6.0. L. m. rhombeata venom $(23 \mathrm{mg}$ ) was dispersed in $500 \mu \mathrm{L}$ of buffer. Flow rate: $0.5 \mathrm{~mL} / \mathrm{min}$; fractions collected: $1.5 \mathrm{~mL} /$ tube. $\mathbf{b}$ Fractionation of LmS-6 on the ion exchange column HiTrap ${ }^{\mathrm{TM}}$ IEX SP XL $(0.7 \times 2.5 \mathrm{~cm}$, $1 \mathrm{~mL}$ ). The sample dispersed in buffer A (0.05 M MES - 2-(N-morpholino) ethanesulfonic acid, pH 6.0) was applied on the column and eluted using a concentration gradient from 0 to $1.0 \mathrm{M} \mathrm{NaCl}$ in the same buffer. Insert SDS-PAGE (13.5\%) under reducing conditions. Lanes 1: molecular mass standard (Sigma cat. M0671); 2: molecular mass standard (GE Healthcare 17-0615-01); 3: L. m. rhombeata venom; 4: Fraction LmrS-6 from molecular exclusion fractionation; 5 and 6: Lmr-MP

\section{Lmr-MP activity in the presence of different inhibitors}

The protease class was determined by activity assay in the presence of different inhibitors: ethylene-diaminetetraacetic acid (EDTA), iodoacetic acid (IAA), pepstatin (PEPS) and phenyl-methylsulfonyl fluoride (PMSF). Lmr-MP $100 \mu \mathrm{L}$ $(0.1 \mathrm{mg} / \mathrm{mL})$ was previously incubated at a final concentration of each inhibitor $(10 \mathrm{mM})$ for $5 \mathrm{~min}$ at $37^{\circ} \mathrm{C}$ [26]. After this previous incubation, $40 \mu \mathrm{L}$ of HEPES buffer (100 mM, pH 8.0) and 1\% azocasein prepared in the same buffer were added. The reaction was performed at $37^{\circ} \mathrm{C}$ for $90 \mathrm{~min}$. It was stopped by adding $400 \mu \mathrm{L}$ of $10 \%(w / V)$ trichloroacetic acid solution. The samples were centrifuged 
at $10,000 \times g$ at $25{ }^{\circ} \mathrm{C}$ for $15 \mathrm{~min}$ and $400 \mu \mathrm{L}$ of the supernatant were transferred to a new tube and mixed with $467 \mu \mathrm{L}$ of sodium hydroxide $(1 \mathrm{M})$. The absorbance was measured in a spectrophotometer at $440 \mathrm{~nm}$. One activity unit $(\mathrm{U})$ was defined as the amount of enzyme required to yield an increase of $0.001 \mathrm{~A}_{440 \mathrm{~nm}}$ under the assays conditions in according to Morita et al. [27]. The residual activity was determined based on control (without inhibitors) activity: Residual activity $=100 \times[$ (Sample activity) $/$ (Control activity) $]$.

\section{Effect of different ions on metalloprotease activity and different $\mathrm{ZnCl}_{2}$ concentrations}

To determine the effect of different ions on enzyme activity, $100 \mu \mathrm{L}$ of Lmr-MP $(0.1 \mathrm{mg} / \mathrm{mL})$ was previously incubated at a final concentration of $10 \mathrm{mM} \mathrm{CoCl}, \mathrm{LiCl}$, $\mathrm{MgCl}_{2}, \mathrm{KCl}, \mathrm{ZnCl}_{2}, \mathrm{NiSO}_{4}, \mathrm{CuCl}_{2}, \mathrm{CaCl}_{2}, \mathrm{MnCl}_{2}, \mathrm{AlCl}_{3}$, $\mathrm{BaCl}_{2}$ and $\mathrm{NaCl}$ at $37{ }^{\circ} \mathrm{C}$ for $5 \mathrm{~min}$, according to Ducros et al. [28] with modifications. The different $\mathrm{ZnCl}_{2}$ concentration (1, 2.5, 5 and $10 \mathrm{mM}$ ) effects on Lmr-MP activity was determined after $5 \mathrm{~min}$ of incubation at $37^{\circ} \mathrm{C}$. After the previous incubation, $40 \mu \mathrm{L}$ of HEPES buffer $(100 \mathrm{mM}$, $\mathrm{pH}$ 8.0) and $1 \%$ azocasein prepared in same buffer were added. The reaction was performed for $90 \mathrm{~min}$ at $37^{\circ} \mathrm{C}$ and was stopped by adding $400 \mu \mathrm{L}$ of $10 \%(w / v)$ trichloroacetic acid solution. The samples were centrifuged at $10,000 \times g$ for $15 \mathrm{~min}$ at $25^{\circ} \mathrm{C}$ and $400 \mu \mathrm{L}$ of the supernatant were transferred to a new tube and mixed with $467 \mu \mathrm{L}$ of $1 \mathrm{M}$ sodium hydroxide. The absorbance was measured in a spectrophotometer at $440 \mathrm{~nm}$. One activity unit (U) was defined as the amount of enzyme required to yield an increase of $0.001 \mathrm{~A}_{440 \mathrm{~nm}}$ under the assays conditions in according to Morita et al. [27].

\section{Lmr-MP activity with different solutions and optimal pH} Lmr-MP activity with $100 \mu \mathrm{L}$ of different solutions and the optimal $\mathrm{pH}$ were performed according to the method of azocasein described in Wang et al. [29]. The sample, fraction LmS-6 $(5 \mu \mathrm{g})$, was incubated with azocasein $(5 \mathrm{mg} / \mathrm{mL})$ in $0.05 \mathrm{M}$ Tris- $\mathrm{HCl}$ buffer, $\mathrm{pH} 8.0$, in the presence of different solutions (5 and $50 \mathrm{mM}$ AMBIC pH 7.8; 0.1\% TFA + 50\% ACN; PBS pH 7.4; $50 \mathrm{mM} \mathrm{NaOAc} \mathrm{pH} 4 ; 50 \mathrm{mM} \mathrm{NH}_{4} \mathrm{OAc} \mathrm{pH} 4.5$ and $50 \mathrm{mM}$ Tris- $\mathrm{HCl} \mathrm{pH} \mathrm{8.0)} \mathrm{at} 37{ }^{\circ} \mathrm{C}$ for $90 \mathrm{~min}$. Another assay was carried out with the LmS-6 fraction $(5 \mu \mathrm{g})$ incubated with azocasein at different pHs (4.5 to 9.0) as described above. The reactions were interrupted with $200 \mu \mathrm{L}$ of $5 \%$ trichloroacetic acid. The mixture was centrifuged at $1000 x g$ for $5 \mathrm{~min}$ and $150 \mu \mathrm{L}$ of each supernatant was transferred to a flat bottom 96-well microplate and added with $150 \mu \mathrm{L}$ of $0.5 \mathrm{M}$ sodium hydroxide. Albumin $(1 \mathrm{mg} / \mathrm{mL})$ was used as negative control and trypsin $(1 \mathrm{mg} / \mathrm{mL})$ as positive control. The absorbance was measured at $450 \mathrm{~nm}$ in the Tecan Sunrise Microplate Reader (Tecan, Switzerland).

\section{Lmr-MP activity upon different substrates}

In Chromogenix ${ }^{\circ}$ chromogenic substrate assay, $5.5 \mu \mathrm{g}$ of Lmr-S6 was incubated with $200 \mu \mathrm{L}$ of each substrate (0.04 mM) - plasmatic kallikrein (S-2302), plasmin and plasminogen activated by streptokinase (S-2251) and Factor Xa (S-2222) for $40 \mathrm{~min}$ at $37{ }^{\circ} \mathrm{C}$ in triplicate. Absorbance reading was performed at $440 \mathrm{~nm}$ in the Tecan Sunrise Microplate Reader.

\section{Statistical analysis}

The statistical analysis was performed with the average and standard deviation (SD) and by analysis of variance (ANOVA) with multiple comparisons (Dunnett's test). The results of $p<0.0001, p<0.01$ and $p<0.05$ were considered statistically significant. The analyses were performed in triplicate.

\section{Results}

\section{Lmr-MP isolation}

Lmr-MP isolation was performed through two chromatographic steps. Figure 1a shows the first step on a HiPrep Sephacryl ${ }^{\circ}$ S-100 HR column, in which 11 fractions were obtained and named LmS-1 to LmS-11. LmS-6 showed previously (data not shown) a metalloprotease activity on azocasein and was subsequently submitted to an ion exchange chromatography on HiTrap ${ }^{\text {tm }}$ IEX SP XL column (Fig. 1b). In this step, three fractions were obtained. The third fraction was responsible for metalloprotease activity on azocasein (as described below) and was named Lmr-MP.

\section{SDS-page}

Figure 1c insert shows the analysis of the LmrV venom by SDS-PAGE. The crude venom, as well as fraction LmS-6 from the first chromatography step and Lmr-MP isolate in the second chromatographic step, were analyzed. The analysis indicates that Lmr-MP was obtained with high purity and that its molecular mass is approximately $23 \mathrm{kDa}$, being this mass consistent with metalloproteases belonging to P-I class.

\section{Mass spectrometry analysis of Lmr-MP}

The MALDI-TOF mass spectrometry of Lmr-MP confirmed its high purity level and the molecular mass determined was $22.85 \mathrm{kDa}$ (Fig. 2a). The amino acid sequence analysis was performed on the gel band in lane 5 (Fig. 1 insert). The gel band was trypsinized and Table 1 shows the main peptides identified. The Lmr-MP sequence was compared and aligned with LHF-II, a metalloprotease from Lachesis muta muta venom and around $90 \%$ of protein sequence was covered (Fig. 2c). The alignment showed that these proteins are very similar although few differences are noted, such as the absence of a potential 


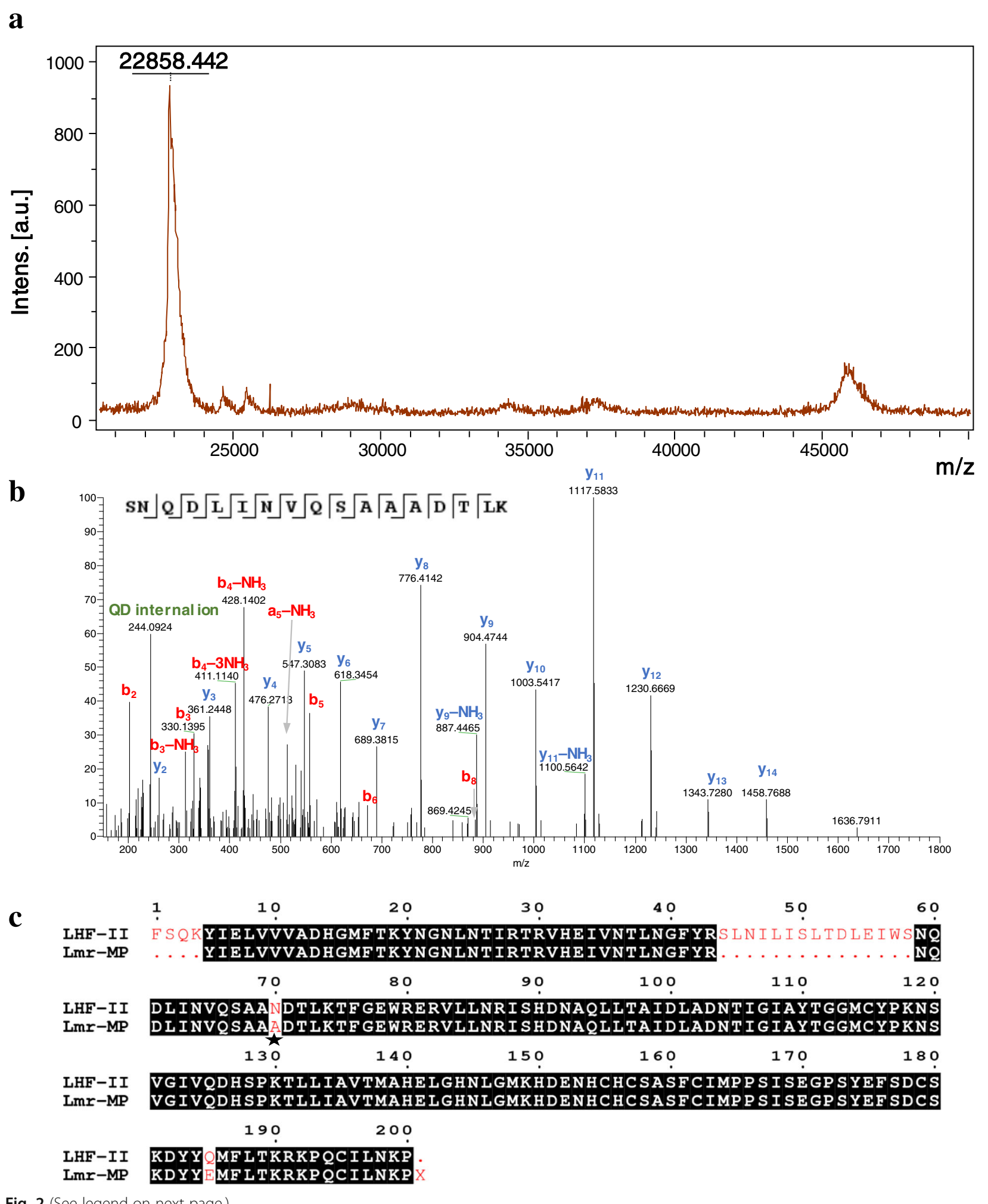

Fig. 2 (See legend on next page.) 
(See figure on previous page.)

Fig. 2 Spectrometry analysis and alignment. a Mass spectrum of Lmr-MP. Molecular mass of Lmr-MP was obtained by MALDI-TOF (positive linear mode) using sinapinic acid (SA) matrix. $\mathbf{b}$ HCD MS/MS of the $(\mathrm{M}+2 \mathrm{H})^{+2}$ ion of the tryptic peptide SNQDLINVQSAAADTLK acquired on an Orbitrap Elite ${ }^{\mathrm{TM}}$ Mass Spectrometer with 15,000 resolution (at $400 \mathrm{~m} / \mathrm{z}$ ). N-terminal ions ( $\mathbf{a}$ and $\mathbf{b}$ ) are shown in red and indicated by $」$ whereas C-terminal ions (y) are shown in blue and indicated by $\Gamma$. Internal ions are shown in green. Mass accuracy for all fragment ions is better than $20 \mathrm{ppm}$. The mass spectrometer used cannot differentiate between leucine and isoleucine residues, and the assignment is made here solely with homology matching. c Sequence alignments of sv-MP hemorrhagic factor-2 (LHF-II) from L. m. muta (UniProt ID P22796) and Lmr-MP from L. m. rhombeata. The highly conserved residues are highlighted in black. Cys residues are shaded gray. Asn-aaX-Ser/Thr residue (star symbol) represents the N-glycosylation site. X = Leu/lle. Alignment and figure were generated by MultAlin and ESPript servers, respectively

$\mathrm{N}$-glycosylation site in the 70th position in Lmr-MP in comparison to LHF-II (Fig. 2b and c).

\section{Lmr-MP activity with different inhibitors}

Lmr-MP proteolytic activity was performed with different inhibitors, as EDTA (an ionic chelator that can act as metalloprotease inhibitor), IAA (cysteine protease inhibitor), PMSF (serine protease inhibitor) and pepstatin (aspartyl protease inhibitor). According to Fig. 3a, Lmr-MP activity was completely abolished when incubated with EDTA, suggesting that this enzyme is a metalloprotease, since EDTA is a zinc chelator.

\section{Effect of different ions and $\mathrm{ZnCl}_{2}$ on Lmr-MP activity}

Lmr-MP activity was evaluated by enzyme incubation with different ions $\left(\mathrm{CoCl}_{2}, \mathrm{LiCl}, \mathrm{MgCl}_{2}, \mathrm{KCl}, \mathrm{ZnCl}_{2}\right.$, $\mathrm{NiSO}_{4}, \mathrm{CuCl}_{2}, \mathrm{CaCl}_{2}, \mathrm{MnCl}_{2}, \mathrm{AlCl}_{3}, \mathrm{BaCl}_{2}$ and $\mathrm{NaCl}$ ). It was observed that $\mathrm{Ca}^{2+}, \mathrm{Mg}^{2+}$ and $\mathrm{Ba}^{2+}$ raised the enzyme activity, whereas $\mathrm{Al}^{3+}, \mathrm{Cu}^{2+}, \mathrm{Ni}^{2+}$ and $\mathrm{Zn}^{2+}$ decreased and inhibited the activity (Fig. 3b). Moreover,
$\mathrm{Zn}^{2+}$, in excess, negatively influences Lmr-MP activity as showed in Figure 3c. Increasing $\mathrm{Zn}^{2+}$ concentration decreases Lmr-MP activity.

\section{LmS-6 activity with different substrate}

LmS-6 fraction was submitted to chromogenic substrates assay, and the substrate plasma kallikrein (S-2302), H-D-Pro-Phe-Arg-pNA sequence, was cleaved after the arginine residue. The $\mathrm{S}-2222$ substrate with the sequence Bz-Ile-Glu-Gly-Arg-pNA was also cleaved, however with lower affinity. Moreover, the S-2251 substrate was not degraded by LmS-6 (Fig. 4a).

\section{Lms-6 activity with different solutions and optimal pH}

The metalloprotease activity in different solutions and the $\mathrm{pH}$ profile were evaluated by azocasein activity with LmS-6 fraction. LmS-6 had the highest activity when incubated with PBS, pH 7.4 and Tris- $\mathrm{HCl}, \mathrm{pH} 8.0$, while the enzyme activity was abolished in $0.1 \%$ TFA $+50 \%$ ACN (Fig. 4b). Moreover, the enzyme was optimally

Table 1 Tryptic peptides identified through MS/MS analysis

\begin{tabular}{|c|c|c|c|c|c|c|c|}
\hline Scan time & Fragmentation mode & MS/MS derived sequence & z & Observed m/z & Calculated m/z & Mass deviation (ppm) & Score \\
\hline 19.56 & HCD & TFGEWRER & 2 & 540.7645 & 540.7647 & -0.37 & 623.7 \\
\hline 5.86 & HCD & VLLNR & 2 & 307.7031 & 307.7028 & 0.97 & 309.1 \\
\hline 28.43 & HCD & SNQDLINVQSAAADTLK & 2 & 894.4609 & 894.4603 & -2.35 & 415.4 \\
\hline 35.27 & HCD & DYYEMFLTK & 2 & 605.2787 & 605.2785 & 0.33 & 288.7 \\
\hline 14.12 & HCD & YNGNLNTIR & 2 & 532.7779 & 532.7778 & 0.19 & 476.3 \\
\hline 10.00 & HCD & NSVGIVQDHSPK & 2 & 640.8334 & 640.8333 & 0.16 & 716.8 \\
\hline 28.43 & HCD & TRVHEIVNTLNGFYR & 2 & 909.9846 & 909.9841 & 0.55 & 730.8 \\
\hline 13.42 & HCD & KPQCILNKP & 2 & 549.3105 & 549.3104 & 0.19 & 431.7 \\
\hline 36.74 & ETD & YIELWADHGMFTK & 3 & 574.6362 & 574.6359 & 0.52 & 722.1 \\
\hline 28.49 & ETD & VHEIVNTLNGFYR & 3 & 521.2755 & 521.2756 & -0.19 & 926.1 \\
\hline 3253 & ETD & ISHDNAQLLTAIDLADNTIGIAYTGGMCYPPK & 5 & 671.3300 & 671.3296 & 0.60 & 1359.6 \\
\hline 9.63 & ETD & NSVGIVQDHSPK & 3 & 427.5580 & 427.5580 & 0 & 707.5 \\
\hline 37.16 & ETD & HDENHCHCSASFCIMPPSISEGPSYEFSDCSK & 5 & 755.3034 & 755.3031 & 0.40 & 1248.5 \\
\hline 32.92 & ETD & TLLIAVTMAAHELGHNLGMK & 4 & 517.0287 & 517.0288 & -0.19 & 1093.1 \\
\hline 9.72 & ETD & RKPQCILNKP & 3 & 418.5764 & 418.5764 & 0 & 545.7 \\
\hline 19.86 & ETD & KPQCILNKPX & 3 & 404.2375 & 404.2374 & 0.25 & 550.7 \\
\hline 18.00 & ETD & RKPQCILNKPX & 3 & 456.2714 & 456.2711 & 0.66 & 383.5 \\
\hline
\end{tabular}

Cys residues are carbamidomethylated and amino acid residues different from the database are shown in bold. $\mathrm{X}$ represents Leu/lle. $\mathrm{M}$ is oxidized Met 
$\mathbf{a}$

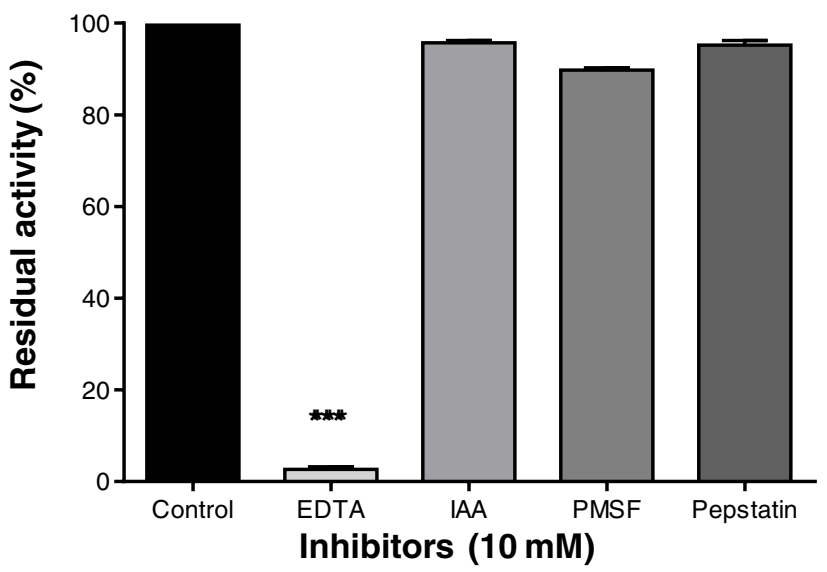

b
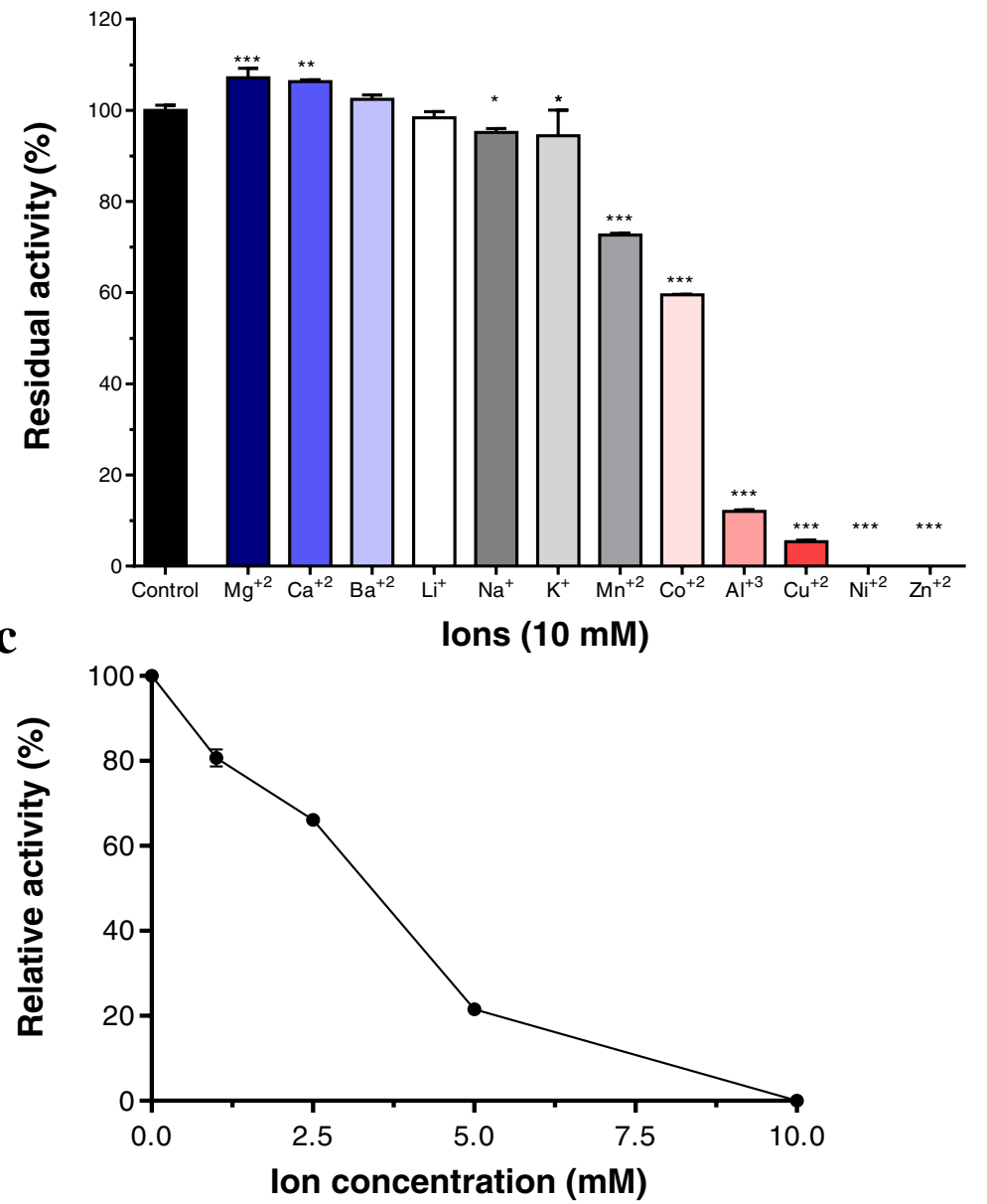

Fig. 3 Enzymatic activity of Lmr-MP upon inhibitors and different ions. a Azocaseinolytic activity of Lmr-MP (10 $\mu \mathrm{g} / 100 \mu \mathrm{L})$ : in the absence (control) or presence of $10 \mathrm{mM}$ different inhibitors (EDTA, IAA, PEPS and PMSF). $\mathbf{b}$ in the presence of $10 \mathrm{mM}$ different ions $\left(\mathrm{CoCl}_{2}, \mathrm{LiCl}, \mathrm{MgCl} 2, \mathrm{KCl}\right.$, $\mathrm{ZnCl}_{2}, \mathrm{NiSO}_{4}, \mathrm{CuCl}_{2}, \mathrm{CaCl}_{2}, \mathrm{MnCl}_{2}, \mathrm{AlCl}_{3}, \mathrm{BaCl}_{2}$ and $\left.\mathrm{NaCl}\right)$. $\mathbf{c}$ in the presence of $\mathrm{ZnCl}_{2}$ at different concentrations (2.5, 5.0, 7.5 and $10 \mathrm{mM}$ ). The reactions were performed at $37{ }^{\circ} \mathrm{C}$. The residual activity was determined based on control activity: Residual activity $=100 \times[($ Sample activity)/ (Control activity)]. ${ }^{*} p<0.05,{ }^{* *} p<0.01$ and ${ }^{* * *} p<0.0001$ compared to the controls (one-way ANOVA, followed by Dunnett's test). Data $(n=3)$ are presented as mean $\pm S D$ 


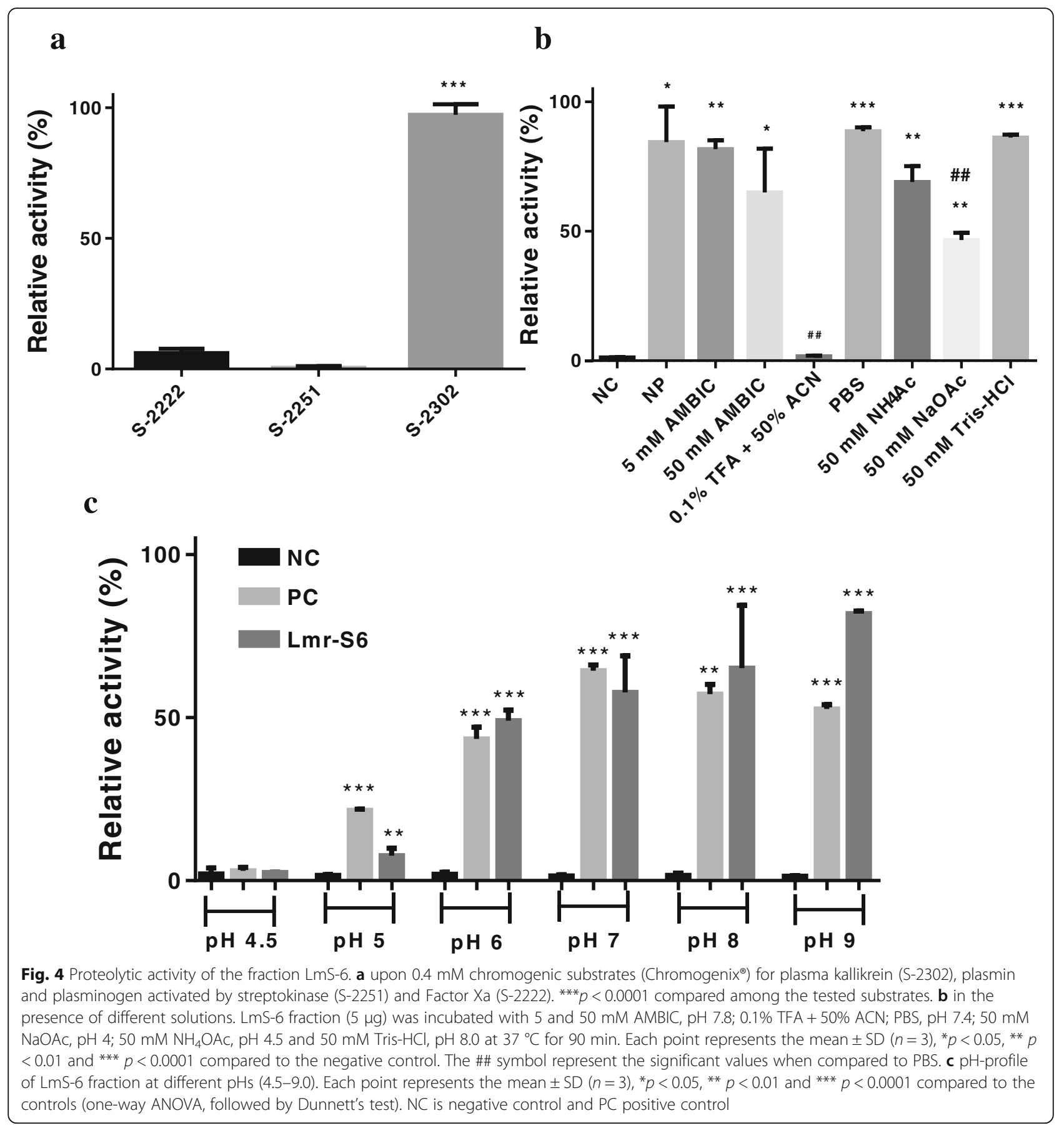

active in a $\mathrm{pH}$ range from 7.0 to 9.0 and the activity decreased in acidic pHs (Fig. 4c).

\section{Discussion}

Accidents caused by Lachesis genus are less common than Crotalus and Bothrops envenomings in Brazil. However, large amount of venom is injected in victims bitten by bushmasters leading to severe symptoms such as hypotension, profuse diarrhoea, oedema and abnormal bleeding [3, 30].
These symptoms can be caused by different proteins and peptides present in Lmr venom.

Few components have been purified from L. muta rhombeata venom until now, including a L-amino acid oxidase, PLA $\mathrm{P}_{2}$, PLB, hyaluronidase, serine protease and BPPs [9, 10, 12, 13]. Although there are studies about these components, little is known about some mechanisms induced by these proteins and peptides, especially in Lachesis envenomation, since its venom is difficult to obtain and is hard to keep bushmasters in captivity [5, 31]. 
In this paper we described the isolation of the first metalloprotease from $L$. $m$. rhombeata subspecies through two chromatographic steps: a molecular exclusion followed by an ion exchange chromatography (Fig. 1). The metalloprotease activity was confirmed by EDTA inhibition on enzymatic assay and no effect caused by other proteases inhibitors (PMSF, IAA and pepstatin) was observed (Fig. 3a). The metalloprotease was named as Lmr-MP and the SDS-PAGE and MALDI-TOF analysis showed that it was efficiently purified (Fig. 1c insert and Fig. 2a). Moreover, the molecular mass determined $(22.85 \mathrm{kDa})$ is in accordance to the mass of other SVMPs and indicates that Lmr-MP is a metalloprotease from P-I class [14, 32, 33].

P-I to P-IIId metalloproteases classification comprehends different multidomains. In P-I case, there is only a signal peptide, a pro-domain and a metalloprotease domain. The signal peptide is responsible for protein secretion, the pro-domain is related to catalytic activation and the metalloprotease domain encodes the enzyme sequence $[16,34]$. In general, P-I class metalloproteases are less haemorrhagic than P-III classes possibly because of the multiple domains associated with P-III sequences [32].

Until now, two metalloproteases have been purified from L. muta muta venom, LHF-I and LHF-II (also named Mutalysin-II) [35-37]. An alignment between only LHF-II and Lmr-MP was performed since both are P-I SVMPs [38]. The alignment revealed high similarity between these enzymes despite differences in some amino acids (Fig. 2c). LHF-II has a N-glycosylation site in Asn70, while Lmr-MP has an Ala in the same position (Fig 2b). The calculated mass of LHF-II, from its primary sequence, was 22,595.77 Da [39]. In comparison to the molecular mass of Lmr-MP determined by MALDI-TOF, the difference between them is only 262.67 Da, consisted with mass variation regarding amino acid substitutions and not due to glycosylations [40]. Furthermore, the change of Asn by Ala in Lmr-MP lead to the loss of a potential N-glycosylation site.

Pla et al. [41] described the proteome analysis of $L a-$ chesis muta rhombeata venom. Around $29.5 \%$ of venom composition was SVMPs (10.3\% of this value are related to metalloproteases from class P-III and 19.2\% from P-I class). The authors found similarity of metalloprotease from P-I class with LHF-II described above. In addition, another study from dos Santos [42], also revealed the presence of one metalloprotease from P-I class similar to LHF-II. The metalloprotease found in both studies are probably the Lmr-MP or an isoform.

Although P-I metalloproteases class have no relevant haemorrhagic activity, they degrade other membrane components and appear to be related to pathogenic effects of local damage observed in envenoming [43]. Because of their fibrinolytic and not haemorrhagic effects, the therapeutic potential of these metalloproteases for thrombolytic events has been studied [37], suggesting a potential therapeutic effect for Lmr-MP.

We evaluated Lmr-MP activity in the presence of different ions (Fig. 3b). The enzymatic activity increased with $\mathrm{Ca}^{2+}, \mathrm{Mg}^{2+}$ and $\mathrm{Ba}^{2+}$. In contrast, the activity was inhibited by $\mathrm{Al}^{3+}, \mathrm{Cu}^{2+}, \mathrm{Ni}^{2+}$ and $\mathrm{Zn}^{2+}$. Therefore, $\mathrm{Lmr}-\mathrm{MP}$ is activated by divalent ions. However, zinc ions inhibited this activity. This inhibition by zinc was dose-dependent, as demonstrated in Fig. 3c. Some previous studies have shown that divalent ions, such as $\mathrm{Ca}^{2+}$, help to stabilize the protein. On the other hand, although $\mathrm{Zn}^{2+}$ is present in metalloprotease structures and is fundamental to proteolytic activity, if in excess, it can inhibit enzyme activity by causing stereochemical disturbances in the stabilization of the molecule [33, 36, 44].

The proteolytic activity of LmS-6 fraction upon chromogenic substrates showed the highest activity when the enzyme was incubated with S-2302, the substrate for plasma kallikrein (H-D-Pro-Phe-Arg-pNA) (Fig. 4a). Plasma kallikrein is important in human physiology, specifically in release of bradykinin (BK). It is activated by factor XIIa and then cleaves high-molecular-mass kininogen to generate bradykinin [45]. Therefore, the metalloprotease isolated in this study may act in important systems, bringing perspectives for the use of Lmr-MP as a therapeutic agent in haemostatic disorders. Despite this, more studies are needed to prove the activity of the enzyme on the substrate and to infer its activity in envenoming and as therapeutic agent.

Additionally, Lmr-MP activity was evaluated in the presence of different solutions, such as 5 and $50 \mathrm{mM}$ AMBIC (pH 7.8), 0.1\% TFA + 50\% ACN, PBS pH 7.4, $50 \mathrm{mM} \mathrm{NaOAc} \mathrm{pH} 4,50 \mathrm{mM} \mathrm{NH}_{4} \mathrm{OAc} \mathrm{pH} 4.5$ and $50 \mathrm{mM}$ Tris- $\mathrm{HCl} \mathrm{pH} \mathrm{8.0.} \mathrm{The} \mathrm{proteolytic} \mathrm{activity} \mathrm{on} \mathrm{azo-}$ casein was higher in $50 \mathrm{mM}$ Tris- $\mathrm{HCl}$ buffer $(\mathrm{pH} 8.0)$ and PBS pH 7.4, which corroborated with optimal $\mathrm{pH}$ analysis (Fig. 4c) in which the optimal range was determined between 7.0 and 9.0 (Fig. 4b and c). Moreover, it was observed the loss of metalloprotease activity in $0.1 \%$ $\mathrm{TFA}+50 \%$ ACN solution (Fig. 4b) when compared to the negative control of the assay, probably due to the loss of its cofactor and because of acetonitrile, which may interrupt hydrophobic and ionic interactions [46]. These results also indicate that the metalloprotease loses its activity in acidic pHs. The MP LHF-II is also stable in the $\mathrm{pH}$ range from 8 to 10 [36].

\section{Conclusion}

In conclusion, the metalloprotease Lmr-MP of 22,858 Da was efficiently purified from $L$. $m$. rhombeata venom. Around $90 \%$ of Lmr-MP total primary sequence was covered and the MS/MS results altogether with de MALDI-TOF analysis showed that this metalloprotease is not glycosylated (Fig. 2b). The enzymatic assays presented 
that ion zinc inhibit its activity in a dose-dependent manner and this enzyme lose activity in acidic pHs. These results open new perspectives for Lachesis venom and metalloproteases knowledge and, although more studies must be performed to provide a therapeutic activity, Lmr-MP showed preferentially inhibit the kallikrein plasma substrate, that plays a critical role in physiological processes, making it a favorable candidate for future pharmaceutical tools.

\section{Abbreviations}

ACN: Acetonitrile; $\mathrm{AlCl}_{3}$ : Aluminium chloride; $\mathrm{AMBIC}$ : Ammonium bicarbonate; ANOVA: Analysis of variance; $\mathrm{BaCl}_{2}$ : Barium chloride; BK: Bradykinin; $\mathrm{CaCl}_{2}$ : Calcium chloride; $\mathrm{CoCl}_{2}$ : Cobalt chloride; $\mathrm{CuCl}_{2}$ : Cupric chloride; EDTA: Ethylenediaminetetraacetic acid; ETD: Electron-transfer dissociation; FPLC: Fast protein liquid chromatography; HCD: High-energy collisional dissociation; HEPES: 4-(2-hydroxyethyl)-1-piperazineethanesulfonic acid; IAA: lodoacetic acid; KCl: Potassium chloride; LAAO: L-aminoacid oxidase; LHF-I and II: Metalloproteases from Lachesis muta muta venom LiCl: Litium chloride; Lmr: Lachesis muta rhombeata; Lmr-MP: Metalloprotease from Lachesis muta rhombeata venom; LmrV: Lachesis muta rhombeata venom; LmS-6: Sixth fraction of the Lachesis muta rhombeata venom on Sephacryl chromatography; Magnesium chloride: Sodium chloride; MALDI-TOF: Matrix Assisted Laser Desorption lonisation; MES: 2-(N-morpholino) ethanesulfonic acid; MetOH: Methanol; $\mathrm{MgCl}_{2}$ : Manganese(II) chloride; $\mathrm{MnCl}_{2}$ : Magnesium chloride; $\mathrm{NaOAc}$ : Sodium acetate; $\mathrm{NH}_{4} \mathrm{OAc}$ : Ammonium acetate; $\mathrm{NiSO}_{4}$ : Nickel sulfate; PBS: Phosphate buffered saline; PEPS: Pepstatin; PLA 2 : Phospholipases $A_{2}$ PLB: Phospholipase B; PMSF: Phenylmethylsulfonyl fluoride; SA: Sinapinic acid; SD: Standard deviation SD; SDS-PAGE: Sodium dodecyl sulfate polyacrylamide gel electrophoresis; sVMPs: Snake venom metalloproteases; TFA: Trifluoracetic acid; Tris- $\mathrm{HCl}$ : Tris hydrochloride buffer; $\mathrm{ZnCl}_{2}$ : Zinc chloride

\section{Funding}

Financial support of Coordination for the Improvement of higher Education Personnel (CAPES Finance Code 001). This study was supported by the National Institute of Health (NIH, USA grant R41 GM103362); São Paulo Research Foundation (FAPESP, grants 2011/23236-4 and scholarship to GAW 2014/23285-3 and BMC 2016/09711-5); Coordination for the Improvement of Higher Education Personnel (CAPES, through Programa Editoração CAPES, edital 13/2016, grant 0722/2017, 88881.142062/2017-01) and National Council for Scientific and Technological Development (CNPq, through Programa Editorial CNPq/CAPES, chamada 26/2017, grant 440954/2017-7; grant 303689/2013-7 and scholarship to FAC 140949/2015-1).

\section{Availability of data and materials}

Not applicable.

\section{Author's contributions}

FAC was responsible for project development, enzyme purification, major part of the assays, analysis of the results and writing of the manuscript. BMC performed the enzymatic experiments and participated in the Lmr-MP isolation. GCW did spectrometry analysis and participated of data interpretation and analysis. KCFB and CBS participated of purification and structural characterization of Lmr-MP. NGRG and HC participated of some enzymatic assays. BU contributed with mass spectrometry analysis and coordinated GCW analysis during her internship. ECA coordinated and designed the experiments and contributed in writing the manuscript. All authors read and approved the final manuscript.

\section{Ethics approval and consent to participate}

Not applicable.

\section{Consent for publication}

Not applicable.

\section{Competing interests}

The authors declare that they have no competing interests.

\section{Publisher's Note}

Springer Nature remains neutral with regard to jurisdictional claims in published maps and institutional affiliations.

\section{Author details}

${ }^{1}$ Department of Physics and Chemistry, School of Pharmaceutical Sciences of Ribeirão Preto, University of São Paulo (USP), Av. do Café $s / n^{\circ}$, Monte Alegre, Ribeirão Preto, SP 14040-903, Brazil. ${ }^{2}$ Universidad Latina de Costa Rica, San José, Costa Rica. ${ }^{3}$ Department of Pharmaceutical Sciences, School of Pharmaceutical Sciences of Ribeirão Preto, University of São Paulo (USP), Ribeirão Preto, SP, Brazil. ${ }^{4}$ Proteomics Resource Center, New York University Langone Medical Center, 430 East 29th St, New York City 10016, USA.

Received: 29 June 2018 Accepted: 1 November 2018

Published online: 22 November 2018

\section{References}

1. Chippaux JP. Epidemiology of envenomations by terrestrial venomous animals in Brazil based on case reporting: from obvious facts to contingencies. J Venom Anim Toxins Incl Trop Dis. 2015;21:13. https://doi. org/10.1186/s40409-015-0011-1.

2. Brasil. Ministério da Saúde. Acidentes por animais peçonhentos Notificações registradas no Sistema de Informação de Agravos de Notificação. 2018.

3. Jorge MT, Sano-Martins IS, Tomy SC, Castro SC, Ferrari RA, Ribeiro LA, et al. Snakebite by the bushmaster (Lachesis muta) in Brazil: case report and review of the literature. Toxicon. 1997;35(4):545-54

4. Cremonez CM, Leite FP, Bordon KD, Cerni FA, Cardoso IA, Gregório ZM, et al. Experimental Lachesis muta rhombeata envenomation and effects of soursop (Annona muricata) as natural antivenom. J Venom Anim Toxins Incl Trop Dis. 2016;22:12. https://doi.org/10.1186/s40409-016-0067-6.

5. Duque $\mathrm{AMH}$, Corrales $\mathrm{G}$. First report of the reproduction in captivity of the Chocoan bushmaster, Lachesis acrochorda (García, 1896). Herpetol Notes. 2015;8:315-20.

6. Stephano MA, Guidolin R, Higashi HG, Tambourgi DV, Sant'Anna OA. The improvement of the therapeutic anti-Lachesis muta serum production in horses. Toxicon. 2005:45(4):467-73.

7. Pardal PPO, Bezerra IS, Rodrigues LS, Pardal JSO, Farias PHS. Acidente por Surucucu (Lachesis muta muta) em Belém-Pará: Relato de caso. Rev Para Med. 2007;21(1):37-42

8. Bolaños R, Muñoz G, Cerdas L. Toxicity, neutralization and immunoelectrophoresis of the venom of Lachesis muta from Costa Rica and Colombia (author's transl). Toxicon. 1978;16(3):295-300.

9. Wiezel GA, dos Santos PK, Cordeiro FA, Bordon KCF, Selistre-de-Araujo HS, Ueberheide $B$, et al. Identification of hyaluronidase and phospholipase $B$ in Lachesis muta rhombeata venom. Toxicon. 2015;107(Pt B):359-68.

10. Cordeiro FA, Perini TG, Bregge-Silva C, Cremonez CM, Rodrigues RS, Boldrini-França J, et al. A new phospholipase A2 from Lachesis muta rhombeata: purification, biochemical and comparative characterization with crotoxin B. Protein Pept Lett. 2015;22(9):816-27.

11. Damico DC, Vassequi-Silva T, Torres-Huaco FD, Nery-Diez AC, de Souza RC, Da Silva SL, et al. LmrTX, a basic PLA 2 (D49) purified from Lachesis muta rhombeata snake venom with enzymatic-related antithrombotic and anticoagulant activity. Toxicon. 2012;60(5):773-81.

12. Bregge-Silva $C$, Nonato $M C$, de Albuquerque $S$, Ho PL, Junqueira de Azevedo IL, Vasconcelos Diniz MR, et al. isolation and biochemical, functional and structural characterization of a novel L-amino acid oxidase from Lachesis muta snake venom. Toxicon. 2012;60(7):1263-76.

13. Pinheiro-Júnior EL, Boldrini-França J, de Campos Araújo LMP, Santos-Filho NA, Bendhack LM, Cilli EM, et al. LmrBPP9: a synthetic bradykininpotentiating peptide from Lachesis muta rhombeata venom that inhibits the angiotensin-converting enzyme activity in vitro and reduces the blood pressure of hypertensive rats. Peptides. 2018;102:1-7.

14. Markland FS Jr, Swenson S. Snake venom metalloproteinases. Toxicon. 2013; 62:3-18.

15. Moura-da-Silva AM, Almeida MT, Portes-Junior JA, Nicolau CA, Gomes-Neto F, Valente RH. Processing of snake venom metalloproteinases: Generation of toxin diversity and enzyme inactivation. Toxins (Basel). 2016;8(6):pii: E183.

16. Fox JW, Serrano SM. Insights into and speculations about snake venom metalloproteinase (SVMP) synthesis, folding and disulfide bond formation and their contribution to venom complexity. FEBS J. 2008;275(12):3016-30. 
17. Calderon LA, Sobrinho JC, Zaqueo KD, de Moura AA, Grabner AN, Mazzi MV, et al. Antitumoral activity of snake venom proteins: new trends in cancer therapy. Biomed Res Int. 2014;2014:203639.

18. Maria DA, da Silva MG, Correia Junior MC, Ruiz IR. Antiproliferative effect of the jararhagin toxin on B16F10 murine melanoma. BMC Complement Altern Med. 2014;14:446.

19. Guimarães DO, Lopes DS, Azevedo FV, Gimenes SN, Silva MA, Achê DC, et al. In vitro antitumor and antiangiogenic effects of Bothropoidin, a metalloproteinase from Bothrops pauloensis snake venom. Int J Biol Macromol. 2017;97:770-7.

20. Urra FA, Araya-Maturana R. Targeting metastasis with snake toxins: molecular mechanisms. Toxins (Basel). 2017;9(12):pii E390.

21. Rowan AD, Litherland GJ, Hui W, Milner JM. Metalloproteases as potential therapeutic targets in arthritis treatment. Expert Opin Ther Targets. 2008; 12(1):1-18.

22. Itoh Y. Metalloproteinases in rheumatoid arthritis: potential therapeutic targets to improve current therapies. Prog Mol Biol Transl Sci. 2017:148:327-38.

23. Kini RM, Koh CY. Metalloproteases affecting blood coagulation, fibrinolysis and platelet aggregation from snake venoms: definition and nomenclature of interaction sites. Toxins (Basel). 2016;8(10):pii: E284.

24. Laemmli UK. Cleavage of structural proteins during the assembly of the head of bacteriophage T4. Nature. 1970;227(5259):680-5.

25. Bern M, Kil YJ, Becker C. Byonic: advanced peptide and protein identification software. Curr Protoc Bioinformatics. 2012;13(13):20.

26. Beynon RJ, Bond JS. Proteolytic enzymes: a practical approach. Oxford: IRL Press at Oxford University Press; 1989.

27. Morita Y, Hasan Q, Sakaguchi T, Murakami Y, Yokoyama K, Tamiya E. Properties of a cold-active protease from psychrotrophic Flavobacterium balustinum P104. Appl Microbiol Biotechnol. 1998;50(6):669-75.

28. Ducros E, Ferrari M, Pellegrino M, Raspanti C, Bogni C. Effect of aeration and agitation on the protease production by Staphylococcus aureus mutant RC128 in a stirred tank bioreactor. Bioprocess Biosyst Eng. 2009;32(1):143-8.

29. Wang WJ, Shih CH, Huang TF. A novel P-I class metalloproteinase with broad substrate-cleaving activity, agkislysin, from Agkistrodon acutus venom. Biochem Biophys Res Commun. 2004;324(1):224-30.

30. Pardal PP, Souza SM, Monteiro MR, Fan HW, Cardoso JL, França FO, et al. Clinical trial of two antivenoms for the treatment of Bothrops and Lachesis bites in the north eastern Amazon region of Brazil. Trans R Soc Trop Med Hyg. 2004;98(1):28-42.

31. Dias L, Rodrigues MA, Rennó AL, Stroka A, Inoue BR, Panunto PC, et al. Hemodynamic responses to Lachesis muta (south American bushmaster) snake venom in anesthetized rats. Toxicon. 2016;123:1-14.

32. Gutiérrez JM, Escalante T, Rucavado A, Herrera C, Fox JW. A comprehensive view of the structural and functional alterations of extracellular matrix by snake venom metalloproteinases (SVMPs): novel perspectives on the pathophysiology of envenoming. Toxins (Basel). 2016;8(10):pii: E304

33. Gutiérrez JM, Rucavado A, Escalante T, Díaz C. Hemorrhage induced by snake venom metalloproteinases: biochemical and biophysical mechanisms involved in microvessel damage. Toxicon. 2005;45(8):997-1011.

34. Ramos OH, Selistre-de-Araujo HS. Snake venom metalloproteases--structure and function of catalytic and disintegrin domains. Comp Biochem Physiol C Toxicol Pharmacol. 2006;142(3-4):328-46.

35. Sánchez EF, Magalhães A, Diniz CR. Purification of a hemorrhagic factor (LHF-I) from the venom of the bushmaster snake, Lachesis muta muta. Toxicon. 1987;25(6):611-9.

36. Sánchez EF, Magalhës A, Mandelbaum FR, Diniz CR. Purification and characterization of the hemorrhagic factor II from the venom of the bushmaster snake (Lachesis muta muta). Biochim Biophys Acta. 1991; 1074(3):347-56.

37. Agero U, Arantes RM, Lacerda-Queiroz N, Mesquita ON, Magalhães A, Sanchez EF, et al. Effect of mutalysin II on vascular recanalization after thrombosis induction in the ear of the hairless mice model. Toxicon. 2007; 50(5):698-706

38. Sanchez EF, Diniz CR, Richardson M. The complete amino acid sequence of the haemorrhagic factor LHFII, a metalloproteinase isolated from the venom of the bushmaster snake (Lachesis muta muta). FEBS Lett. 1991;282(1):178-82.

39. Gasteiger E, Hoogland C, Gattiker A, Duvaud S, Wilkins MR, Appel RD, et al. Protein identification and analysis tools on the ExPASy Server. In: The Proteomics Protocols Handbook, Humana Press. Walker JM editor. 2005. pp. 571-607.

40. Parker CE, Mocanu V, Mocanu M, Dicheva N, Warren MR. Mass spectrometry for post-translational modifications. Alzate O, editor. Neuroproteomics. Boca
Raton: CRC Press/Taylor \& Francis; 2010. Available from: https://www.ncbi. nlm.nih.gov/books/NBK56018/

41. Pla D, Sanz L, Molina-Sánchez P, Zorita V, Madrigal M, Flores-Díaz M, et al. Snake venomics of Lachesis muta rhombeata and genus-wide antivenomics assessment of the paraspecific immunoreactivity of two antivenoms evidence the high compositional and immunological conservation across Lachesis. J Proteome. 2013;89:112-23.

42. dos Santos PK. Proteoma da peçonha de Lachesis muta rhombeata. Universidade Federal de São Carlos, Departamento de Ciências Fisiológicas; 2013. https://repositorio.ufscar.br/handle/ufscar/5511. Acessed 20 Aug 18.

43. Rucavado A, Flores-Sánchez E, Franceschi A, Magalhaes A, Gutiérrez JM. Characterization of the local tissue damage induced by LHF-II, a metalloproteinase with weak hemorrhagic activity isolated from Lachesis muta muta snake venom. Toxicon. 1999;37(9):1297-312.

44. Gomez-Ortiz M, Gomis-Rüth FX, Huber R, Avilés FX. Inhibition of carboxypeptidase a by excess zinc: analysis of the structural determinants by X-ray crystallography. FEBS Lett. 1997:400(3):336-40.

45. Bryant JW, Shariat-Madar Z. Human plasma kallikrein-kinin system: physiological and biochemical parameters. Cardiovasc Hematol Agents Med Chem. 2009;7(3):234-50.

46. Gekko K, Ohmae E, Kameyama K, Takagi T. Acetonitrile-protein interactions: amino acid solubility and preferential solvation. Biochim Biophys Acta. 1998; 1387(1-2):195-205.

\section{Ready to submit your research? Choose BMC and benefit from:}

- fast, convenient online submission

- thorough peer review by experienced researchers in your field

- rapid publication on acceptance

- support for research data, including large and complex data types

- gold Open Access which fosters wider collaboration and increased citations

- maximum visibility for your research: over $100 \mathrm{M}$ website views per year

At BMC, research is always in progress.

Learn more biomedcentral.com/submissions 